75 巻 752 号 (2009-4)

\title{
SMP 粒子強化 SMP インテリジェントマテリアルの 巨視的損失係数の解析*
}

\author{
荒木 栄 敏*1, 杉 本 明 男*2 \\ 山下 浩 儀*3, 小野 裕 之*1
}

\section{Micromechanical Analysis of Macroscopic Loss Factor of a SMP Reinforced SMP Intelligent Material}

\author{
Shigetoshi ARAKI*4, Akio SUGIMOTO, \\ Hironori YAMASHITA and Hiroyuki ONO \\ ${ }^{* 4}$ Mechanical and System Engineering, Kyoto Institute of Technology, \\ Goshokaido-cho, Matsugasaki, Sakyo-ku, Kyoto-shi, Kyoto, 606-8585 Japan
}

\begin{abstract}
A loss factor of a polymeric material which influences its vibration damping capacity strongly is high in value nearby its glass transition temperature. Therefore, when the constituents of a polymer-based composite material are various in their glass transition temperatures, the magnitude of the macroscopic loss factor of such a composite may be expected to be high within wider range in temperature. In the present study, a shape memory polymer (SMP) particle/SMP matrix is used as a sample material and its macroscopic complex modulus and loss factor are derived explicitly by using the equivalent inclusion method combined with the Mori-Tanaka's theorem. Consequently, for the case of a five mode type of distribution of the glass transition temperature of particle whose aspect ratios is 0.01 , the value of the macroscopic loss factor becomes higher than that of the monolithic SMP and it becomes constant within the temperature range from $30^{\circ} \mathrm{C}$ to $70^{\circ} \mathrm{C}$.
\end{abstract}

Key Words : Equivalent Inclusion Method, Loss Factor, Shape Memory Polymer, Glass Transition Temperature, Polymer Based Composite

\section{1. 緒}

高分子材料は，そのガラス転移点近傍において制振 特性が大きく向上するという性質を有する(1)。そのた め，幅広い温度範囲で良好な制振特性を有する材料を 創製するには，異なるガラス転移点を有する構成要素 を組合せて複合化する必要がある。このような複合材 料の巨視的な損失係数は, 線形粘弾性体の定常応答に おける応力ーひずみ関係と弾性体の構成式が形式的に 一致することを利用して，マイクロメカニックスの手 法を用いて複合材料の巨視的弾性定数を求め，これに 含まれる構成要素の弹性定数を複素量に変擙すること で求められる(2)。前報(3)では，この手法をガラス転移 点がー $30^{\circ} \mathrm{C} \sim 70^{\circ} \mathrm{C}$ 範囲で比較的自由に設定できると いう特徴を有するポリウレタン系の形状記憶ポリマー $(\mathrm{SMP})^{(4)(5)}$ 複合材料に適用し，ガラス転移点が $70^{\circ} \mathrm{C}$ の母材中に, $30^{\circ} \mathrm{C} ら 60^{\circ} \mathrm{Cまで} 10^{\circ} \mathrm{C}$ 刻みのガラス転

* 原稿受付 2008 年 9 月 5 日.

*1 正員, 京都工芸瀻維大学大学院工芸科学研究科機械システム 工学専攻 (严606-8585 京都市左京区松ヶ崎御所海道町).

*2 正員, (株) 神户製鋼所技術開発本部機械研究所 (핑 651-2271 神戸市西区高塚台 1-5-5)。

*3 正員, 三菱電機(株)生産技術センター(覀661-8661 尼㱦市 塚口本町 8-1-1).

E-mail : araki@mech.kit.ac.jp
移点を有する球形 SMP 粒子を分散させた場合に, $20^{\circ} \mathrm{C} \sim 80^{\circ} \mathrm{C}$ 幅広い温度範囲に渡って, 巨視的損失係 数が母材単体のそれより大きくなることを見出した。 この結果を受けて, 本研究では, SMP 強化基材のガ ラス転移点分布に加えて強化基材の形状も様々な楕円 体形状に変化させることで，さらに巨視的損失係数が 良好な SMP 複合材料が開発できるかどうかを検討す ることを目的とする。

\section{SMP 複合材料のモデル化と 巨視的損失係数の解析}

\section{$2 \cdot 1$ 幾何学的モデル化 図 1 はSMP 母材 $D$ 中} に種々のガラス転移点を有する SMP 粒子が完全にラ ンダムに存在する状態を示したものであり，そのガラ 又転移点の値によって, ガラス状態, ゴム状態及びそ れらの中間の遷移状態にある粒子が混在している。ま た, SMP 粒子の形状は任意の楕円体で，その主半軸 の大きさは様々であるが，その方向は座標軸と一致し ているものとする。これらの粒子はそのガラス転移点 と形状によって区別され，各領域を $\Omega(i)$ と表すこと にする。母材と粒子 $\Omega(i)$ の複素剛性率を $\mu^{c} と$

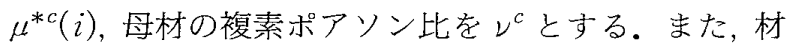
料 $D$ に は定常振動作用せん断応力 $\sigma_{23}^{0} \exp (i \omega t)$, 
$\sigma_{32}^{0} \exp (i \omega t)$ が作用しているものとする。

\section{$2 \cdot 2 \mathrm{SMP}$ 複合材料の巨視的剛性率の解析}

$2 \cdot 2 \cdot 1$ 線形弾性モデルと粒子の等価固有ひずみ 図 2 は図 1 亿対応する線形弾性モデルであり， $\sigma_{23}^{0}$ と $\sigma_{32}^{0}$ が作用するものとする。このとき，粒子の等価式 は, $\Omega(i)$ 内で,

$$
\begin{aligned}
& \sigma_{i j}^{0}+\tilde{\sigma}_{i j}+\sigma_{i j}^{\infty}(i) \\
& \quad=C_{i j k l}^{*}(i)\left[\varepsilon_{k l}^{0}+\widetilde{\varepsilon}_{k l}+S_{k l m n}(i) \varepsilon_{m n}^{*}(i)\right] \\
& \quad=C_{i j k l}\left[\varepsilon_{k l}^{0}+\widetilde{\varepsilon}_{k l}+S_{k l m n}(i) \varepsilon_{m n}^{*}(i)-\varepsilon_{k l}^{*}(i)\right]
\end{aligned}
$$

となる。ここで $C_{i j k l}$ と $C_{i j k l}^{*}(i)$ は，それぞれ母材と $\Omega(i)$ 粒子の弾性定数であり, $S_{i j k l}(i)$ は $\Omega(i)$ の. Eshelby テンソルである.また, $\varepsilon_{i j}^{*}(i)$ は母材と $\Omega(i)$ の弾 性定数の違いを代行する等価固有ひずみ, $\sigma_{i j}^{\infty}(i)$ は固 有応力である。 $\sigma_{i j}^{0}$ と $\varepsilon_{i j}^{0}$ は作用応力と作用ひずみ， $\tilde{\sigma}_{i j}$ と $\widetilde{\varepsilon}_{i j}$ は相互作用場であり，これらの間に，

$$
\sigma_{i j}^{0}=C_{i j k l} \varepsilon_{k l}^{0}, \quad \tilde{\sigma}_{i j}=C_{i j k l} \widetilde{\varepsilon}_{k l}
$$

なる関係がある。

等価式（1）をせん断成分についてのみ書き直し，作 用応力の対称性 $\sigma_{23}^{0}=\sigma_{32}^{0}$ と固有ひずみの対称条件 $\varepsilon_{23}^{*}(i)=\varepsilon_{32}^{*}(i)$ を用いると，

$$
\begin{aligned}
& 2 \mu^{*}(i)\left[\varepsilon_{23}^{0}+\tilde{\varepsilon}_{23}+2 S_{2323}(i) \varepsilon_{23}^{*}(i)\right] \\
& \quad=2 \mu\left[\varepsilon_{23}^{0}+\tilde{\varepsilon}_{23}+2 S_{2323}(i) \varepsilon_{23}^{*}(i)-\varepsilon_{23}^{*}(i)\right]
\end{aligned}
$$

となる.ここで $\mu$ と $\mu^{*}(i)$ は母材と $\Omega(i)$ の剛性率で ある。また, Eshelbyテンソル $S_{2323}(i)$ は, 棈円体 $\Omega(i)$ の形状に拘らず,

$$
S_{2323}(i)=\frac{1}{2}\left[H_{2}^{e}(i)+H_{3}^{e}(i)\right]-\frac{\left[H_{2}^{e}(i)-H_{23}^{e}(i)\right]}{2(1-\nu)}
$$

なる形に整理できる(6).ここでレは母材のポアソン

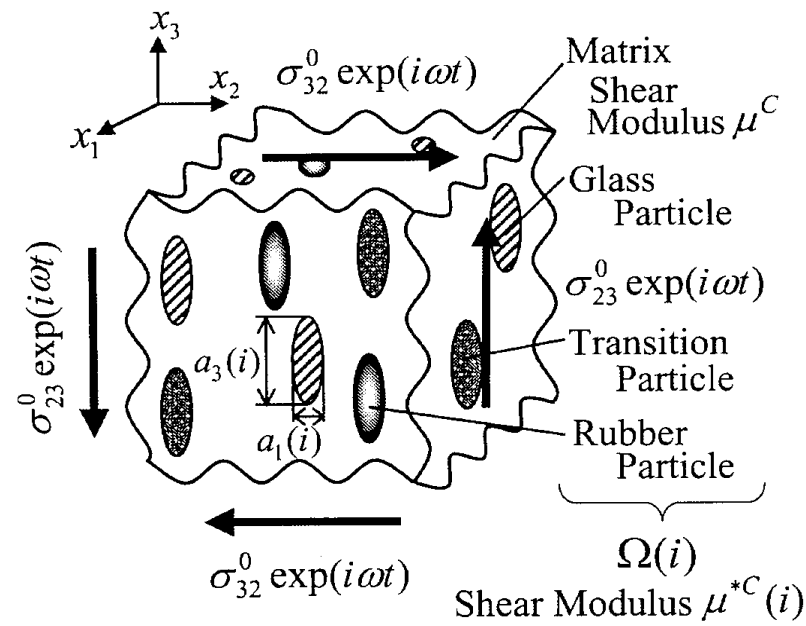

Fig. 1 Polymer based composite
比, $H_{i}^{e}(i)$ と $H_{i j}^{e}(i)$ は, 共に強化基材のアスペクト比 のみの関数である。著者らは $H_{i}^{e}(i)$ と $H_{i j}^{e}(i)$ を形状 因子() と名づけている. 後の $2 \cdot 3$ 節に示すように, 巨 視的損失係数を解析する際には，本節で導く巨視的剛 性率㳊含まれる構成要素の材料定数を複素量に置き換 えるという処置を行うため, 式 (4) に示した形状因子 で整理された Eshelby テンソルを使用することは母 材のポアソン比が完全に分離されているため極めて好 都合であることがわかる。任意の楕円体形状を取り扱 えることに加えて，この点も形状因子を用いる利点で 西る。

式 (4)を等価式 (3)に代入すると，等価固有ひずみ $\varepsilon_{23}^{*}(i)$ は,

$$
\varepsilon_{23}^{*}(i)=-A(i)\left(\varepsilon_{23}^{0}+\tilde{\varepsilon}_{23}\right) \cdots
$$

となる。ここで,

$$
\begin{aligned}
& A(i)=\frac{[g(i)-1]}{[g(i)-1]\left\{\left[1-H_{1}^{e}(i)\right]-\frac{H_{2}^{e}(i)-H_{23}^{e}(i)}{(1-\nu)}\right\}+1} \\
& g(i)=\frac{\mu^{*}(i)}{\mu}
\end{aligned}
$$

で西る。さらに，相互作用応力 $\tilde{\sigma}_{i j}$ は， $\Omega(i)$ の体積含 有率を $f(i)$ と扔くと, Mori-Tanaka の定理(7) 上り,

$$
\tilde{\sigma}_{i j}=-\sum_{i} f(i) \sigma_{i j}^{\infty}(i)
$$

となるため, 相互作用ひずみ $\tilde{\varepsilon}_{23}$ は, 式 (2)に式 (7) を代入した後, さらに式(1) と式 (2) から求まる固有 応力 $\sigma_{i j}^{\infty}(i)$ を代入して, 対称性を考慮して整理する と,

$$
\tilde{\varepsilon}_{23}=-\sum_{i} f(i) B(i) \varepsilon_{23}^{*}(i)
$$

となる.ここで,

$$
B(i)=-H_{1}^{e}(i)-\frac{\left[H_{2}^{e}(i)-H_{23}^{e}(i)\right]}{(1-\nu)}
$$

である. 式(8)に式(5)を代入し， $\varepsilon_{23}^{0}$ と $\widetilde{\varepsilon}_{23}$ が $D$ 内

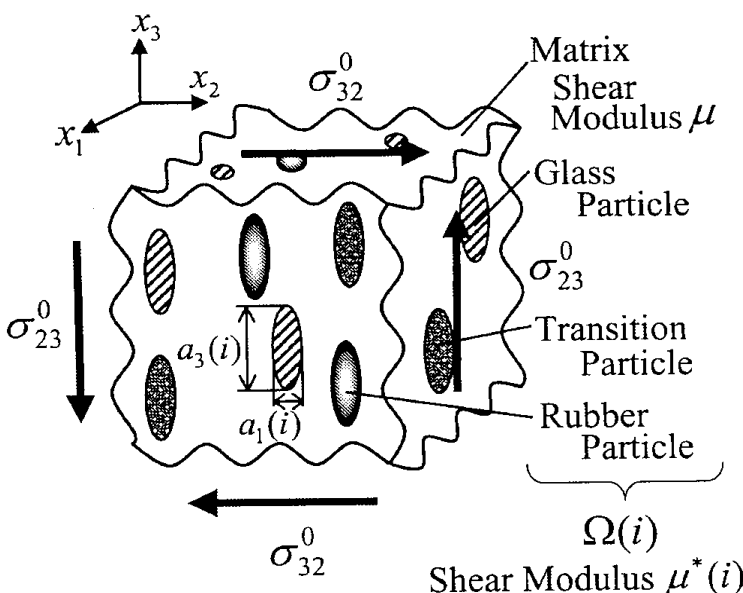

Fig. 2 Linear elastic model 
で一様であることを考慮すると，

$$
\begin{aligned}
& \tilde{\varepsilon}_{23}=\left(\varepsilon_{23}^{0}+\widetilde{\varepsilon}_{23}\right) \sum_{i} f(i) A(i) B(i) \\
& \therefore \quad \tilde{\varepsilon}_{23}=\frac{\sum_{i} f(i) A(i) B(i)}{1-\sum_{i} f(i) A(i) B(i)} \varepsilon_{23}^{0}
\end{aligned}
$$

を得る。式(10)を式(5)に代入すると，等価固有ひず みは最終的に，

$$
\varepsilon_{23}^{*}(i)=-\frac{A(i)}{1-\sum_{i} f(i) A(i) \overline{B(i)}} \varepsilon_{23}^{0}
$$

となる。

$2 \cdot 2 \cdot 2$ 巨視的剛性率 物体 $D$ 内に生じる巨視的 平均ひずみ $\bar{\varepsilon}_{i j}$ は,

$$
\bar{\varepsilon}_{i j}=\varepsilon_{i j}^{0}+\sum_{i} f(i) \varepsilon_{i j}^{*}(i)
$$

となる(6).これに式(11) を代入すると，

$$
\bar{\varepsilon}_{23}=\frac{1-\sum_{i} f(i) A(i)[B(i)+1]}{1-\sum_{i} f(i) A(i) B(i)} \varepsilon_{23}^{0}
$$

を得る。巨視的剛性率

$$
\bar{\mu}=\frac{\sigma_{23}^{0}}{2 \bar{\varepsilon}_{23}}=\frac{\varepsilon_{23}^{0}}{\bar{\varepsilon}_{23}} \mu
$$

により求められるため, 式(14)に式(13)代入すると,

$$
\frac{\bar{\mu}}{\mu}=\frac{1-\sum_{i} f(i) A(i) B(i)}{1-\sum_{i} f(i) A(i)[B(i)+1]}
$$

を得る。

\section{$2 \cdot 3$ SMP 複合材料の巨視的損失係数の解析 弾} 性モデルの解(15)に対して,

$$
\begin{array}{r}
\mu \rightarrow \mu^{c}=\mu^{\prime}+i \mu^{\prime \prime}=\mu^{\prime}(1+i \tan \delta) \cdots \cdots \cdots(16 \cdot \mathrm{a}) \\
\begin{aligned}
\mu^{*}(i) \rightarrow \mu^{* c}(i) & =\mu^{* \prime}(i)+i \mu^{* \prime \prime}(i) \\
& =\mu^{* \prime}(i)\left[1+i \tan \delta^{*}(i)\right] \cdots(16 \cdot \mathrm{b})
\end{aligned} \\
\nu \rightarrow \nu^{c}=\nu^{\prime}+i \nu^{\prime \prime} \cdots \cdots \cdots \cdots \cdots \cdots \cdots \cdots \cdots \cdots \cdots \cdots \cdots \cdots \cdots \cdots \cdots \cdots \cdots \cdots \cdot(16 \cdot \mathrm{c})
\end{array}
$$

なる置き換えを行う。添字 $c$ は複素量を示し $i=$ $\sqrt{-1}$ である。また, $\tan \delta と \tan \delta^{*}(i)$ はそれぞれ母 材と粒子 $\Omega(i)$ の損失係数である.さらに，式 $(6)$ と 式(9)の係数 $g(i), A(i), B(i)$ についても,

$$
\begin{aligned}
& g(i) \rightarrow g^{c}(i)=g^{\prime}(i)+i g^{\prime \prime}(i) \cdots \cdots \cdots \cdots \cdots(17 \cdot \mathrm{a}) \\
& A(i) \rightarrow A^{c}(i)=A^{\prime}(i)+i A^{\prime \prime}(i) \cdots \cdots \cdots \cdots \cdots(17 \cdot \mathrm{b}) \\
& B(i) \rightarrow B^{c}(i)=B^{\prime}(i)+i B^{\prime \prime}(i) \cdots \cdots \cdots \cdots \cdots(17 \cdot \mathrm{c})
\end{aligned}
$$

なる置き換えを行うと，最終的に，巨視的複素剛性率 は,

$$
\begin{aligned}
\bar{\mu}^{c} & =\frac{1-\sum_{i} f(i) A^{c}(i) B^{c}(i)}{1-\sum_{i} f(i) A^{c}(i)\left[B^{c}(i)+1\right]} \mu^{c} \\
& =\left(F^{\prime}+i F^{\prime \prime}\right)\left(\mu^{\prime}+i \mu^{\prime \prime}\right) \\
& =\mu^{\prime}\left[\left(F^{\prime}-F^{\prime \prime} \tan \delta\right)+i\left(F^{\prime} \tan \delta+F^{\prime \prime}\right)\right]
\end{aligned}
$$

となる。ここで各係数は，

$$
\begin{aligned}
& F^{\prime}=\frac{\left(1-G_{1}\right)\left(1-G_{3}\right)+G_{2} G_{4}}{\left(1-G_{3}\right)^{2}+G_{4}^{2}} \cdots \cdots \cdots \cdots(19 \cdot \mathrm{a}) \\
& F^{\prime \prime}=\frac{\left(1-G_{1}\right) G_{4}-G_{2}\left(1-G_{3}\right)}{\left(1-G_{3}\right)^{2}+G_{4}^{2}} \cdots \cdots \cdots \cdots(19 \cdot \mathrm{b}) \\
& G_{k}=\sum_{i} G_{k}(i), \quad(k=1,2,3,4) \cdots \cdots \cdots \cdots \cdots(19 \cdot \mathrm{c}) \\
& G_{1}(i)=f(i)\left[A^{\prime}(i) B^{\prime}(i)-A^{\prime \prime}(i) B^{\prime \prime}(i)\right] \cdots(19 \cdot \mathrm{d}) \\
& G_{2}(i)=f(i)\left[A^{\prime}(i) B^{\prime \prime}(i)+A^{\prime \prime}(i) B^{\prime}(i)\right] \cdots(19 \cdot \mathrm{e}) \\
& G_{3}(i)=f(i)\left\{A^{\prime}(i)\left[B^{\prime}(i)+1\right]-A^{\prime \prime}(i) B^{\prime \prime}(i)\right\} \\
& \cdots \cdots \cdots \cdots(19 \cdot \mathrm{f}) \\
& G_{4}(i)=f(i)\left\{A^{\prime}(i) B^{\prime \prime}(i)+A^{\prime \prime}(i)\left[B^{\prime}(i)+1\right]\right\}
\end{aligned}
$$

である。

巨視的剛性率 $\bar{\mu}^{c}$ を, $\bar{\mu}^{c}=\bar{\mu}^{\prime}+i \bar{\mu}^{\prime \prime}$ で表すと, 式 (18) 加ら,

$$
\begin{aligned}
& \bar{\mu}^{\prime}=\mu^{\prime}\left(F^{\prime}-F^{\prime \prime} \tan \delta\right) \cdots \cdots \cdots \cdots \cdots \cdots \cdots \cdots \cdots \cdots \cdots \cdots \cdots(20 \cdot \mathrm{a}) \\
& \bar{\mu}^{\prime \prime}=\mu^{\prime}\left(F^{\prime} \tan \delta+F^{\prime \prime}\right) \cdots \cdots \cdots \cdots \cdots \cdots \cdots \cdots \cdots(20 \bullet \mathrm{b})
\end{aligned}
$$

となる。さらに，これらの比を取ることにより，巨視 的損失係数 $\tan \bar{\delta}$ は次式となる.

$$
\tan \bar{\delta}=\frac{\bar{\mu}^{\prime \prime}}{\overline{\mu^{\prime}}}=\frac{F^{\prime} \tan \delta+F^{\prime \prime}}{F^{\prime}-\bar{F}^{\prime \prime} \tan \delta}
$$

\section{3. 数值計算結果および考察}

$3 \cdot 1$ 材料定数 解析に際しては, ガラス転移点 $T_{g}$ がー $30^{\circ} \mathrm{C} \sim 70^{\circ} \mathrm{C}$ 範囲で比較的自由に設定できる ポリウレタン系形状記憶ポリマー (SMP) 複合材料を 想定した。SMPの剛性率 $\mu^{\prime}$ とポアソン比レ'は,い ずれも $T_{g}$ の值によらず $T_{g}$ からの温度差に対して同 じ温度変化をするものと仮定した(1)(8).これらをそれ ぞ机図 3(a) と図 3(b)に示す。また，これは損失係 数 $\tan \delta$ についても同様であり, $T_{g}=70^{\circ} \mathrm{C}$ 場合にお ける温度変化を図 $3(\mathrm{c})$ に示す(1). 母材の $T_{g}$ は $70^{\circ} \mathrm{C}$, ポアソン比の虚部レ゙は零とした。さらに。前報(3) 同様に，母材が高温域，粒子が低温域での制振特性を それぞれ受け持つものとし，粒子のガラス転移点を母 材より低温側に設定するとともに，その体積含有率 $f$ を, ちょうど半分の值，すなわち $f=0.5$ に設定した。

$3 \cdot 2$ 強化基材形状の影響 本節では強化基材形 状が巨視的損失係数へ及济す影響を明らかにするた め, 粒子は 1 種類，すなわち，ガラス転移点分布は単 分散とし，ガラス転移点を $30^{\circ} \mathrm{C}$ に設定した。また，粒 子の形状としては, フレーク，棈円柱，回転棈円体の 3 種類を用いた。このような粒子を用いた場合には，そ の損失係数は異方性を示すことになる。しかしなが ら, 特に, フレークや薄い楕円柱の場合には，その主 半軸の大きさが最も小さくなる方向に垂直な面に沿っ てせん断振動応力を加えた場合にのみ，その制振能が 


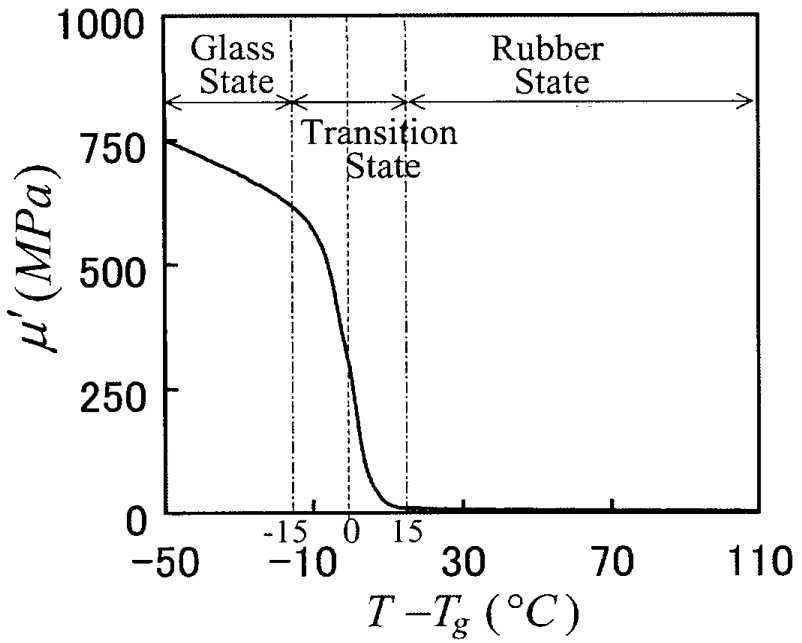

(a) Shear modulus of SMP

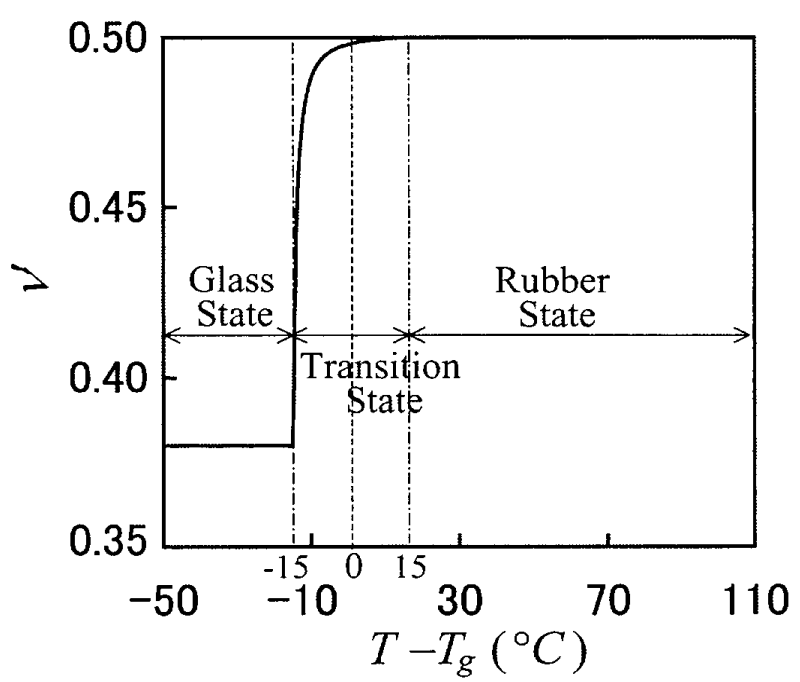

(b) Poisson's ratio of SMP



(c) $\tan \delta$ of SMP

Fig. 3 Elastic constants and tan of of SMC
発露されるものと考えられる。したがって，式(21)で 求めた巨視的損失係数が $\sigma_{23}^{o} \exp (i \omega t)=\sigma_{32}^{o} \exp (i \omega t)$ なる作用応力に対するものであることを考慮して，フ レークにおいては，その主半軸の大きさの順序を $a_{3}>a_{1} \gg a_{2}$, 楕円柱では $a_{3} \gg a_{1}>a_{2}$, 回転棈円体では $a_{3}>a_{1}=a_{2}$ とした.

図 4 に, 強化基材形状がフレーク $\left(a_{3}>a_{1} \gg a_{2}\right)$ の場 合に対する巨視的損失係数 $\tan \bar{\delta}$ の温度変化を示す. フレーク面に垂直な方向が $x_{2}$ 方向(図 1 参照)であり, その厚さ $\omega_{2}=a_{2} / a_{1}$ は， $\omega_{2}=0.01$ とした。また，図は $\omega_{3}=a_{3} / a_{1}$ を変化させた結果である.なお，図中の破 線は母材単体に対する結果(1)を示したものである.

図より，強化基材のアスペクト比 $\omega_{3}$ の值のいかん

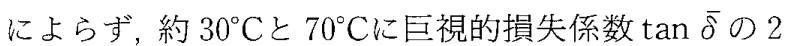
つのピークが生じることがわかる．前者は粒子の $T_{g}$ に，後者は母材のそれに対応するものである．粒子の アスペクト比 $\omega_{3}$ が 1 から増加するにしたがって, $30^{\circ} \mathrm{C}$ の゚ークの值はほとんど変化しないものの, $70^{\circ} \mathrm{C}$ のピーク值は母材単体のものに比べて半分程度にまで 低下することがわかる。また， $\omega_{3}$ が増加するにした がってその低下の度合いはかなり大きくなることもわ かる、したがって，フレークを加えた場合には，その アスペクト比に関係なく $30^{\circ} \mathrm{C}$ 近傍の制振性能は変化 しないが，70Cでの性能は著しく低下することがわか る.

次に，楕円柱 $\left(a_{3} \gg a_{1}>a_{2}\right)$ 強化基材に対する結果を 図 5 に示す。この場合には，図中に示すように， $\omega_{3}$ $\rightarrow \infty$ と $x_{3}$ 方向に長い棈円柱であり, アスペクト比 $\omega_{2}$ $=a_{2} / a_{1}$ を 0.01 ，すなわちリボン状から， $\omega_{2}=1$ の円 柱まで変化させている。図より， $\omega_{2}=0.01$ リボン 状に対しては，図 4 のフレークの場合と同様に $70^{\circ} \mathrm{C}$ の

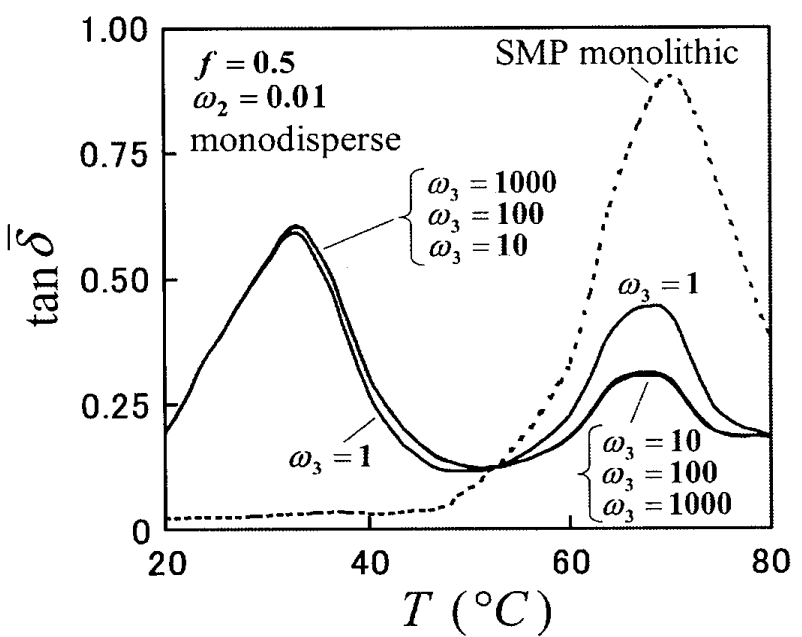

Fig. 4 Macroscopic loss factor (elliptic flake) 
落ち込みが激しいことがわかる。しかしながら， $\omega_{2}$


し，70Cのそれは増加する傾向にあることがわかる。

図 6 は回転棈円体 $\left(a_{3}>a_{1}=a_{2}\right)$ 強化基材に対する 結果である.アスペクト比 $\omega_{3}=a_{3} / a_{1}$ を 100 から減少

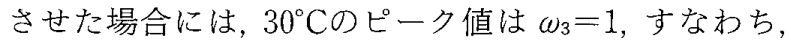
球形になるまで減少するが，その後は逆に増加に転じ, $\omega_{3}=0.01$ で最大となることがわかる. また, $70^{\circ} \mathrm{C} の$ ピーク值はこれとは逆の傾向を示している.

したがって，これらの結果より，強化基材形状が楕 円柱と回転棈円体の場合には，強化基材の体積含有率 が同じ場合においても強化基材のアスペクト比を変化 させることで, $30^{\circ} \mathrm{C}$ と $70^{\circ} \mathrm{C}$ に扔ける巨視的損失係数 $\tan \delta$ の大きさ制御できる可能性があることがわか った，図 7 は，これを検討するために図4～図6での $30^{\circ} \mathrm{C}$ と $70^{\circ} \mathrm{C}$ おける巨視的損失係数のピーク值

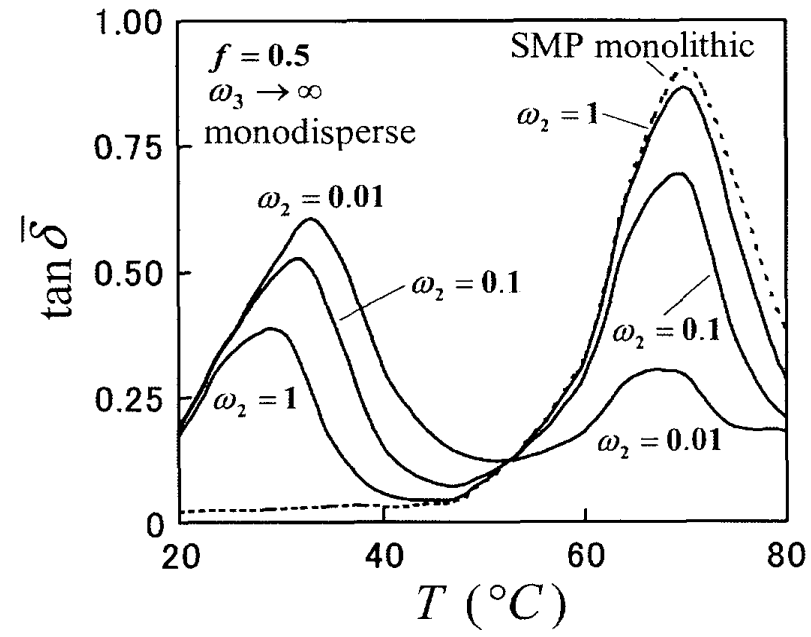

Fig. 5 Macroscopic loss factor (elliptic cylinder)

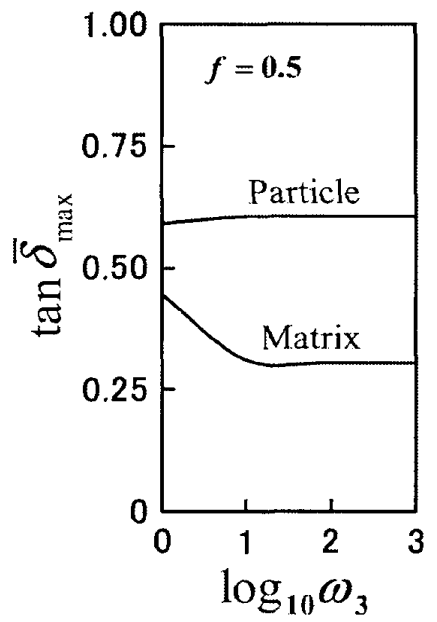

(a) Flake

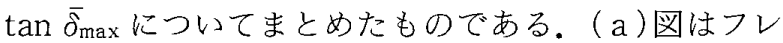
一ク，(b)図は楕円柱，(c)図は回転棈円体強化基材 の場合であり，いずれも横軸は粒子のアスペクト比で ある。また，図中の Matrix は $70^{\circ} \mathrm{C} の$, Particle は $30^{\circ} \mathrm{C}$ の゚ーーク值を表している。これらの図より"，母材

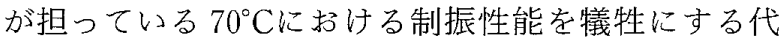
わりに，30Cでの制振性能を効率よく向上させるため には，粒子の含有率 $f$ が $50 \%$ であることを鑑みて，母 材と粒子に対応するピークの值を一致させるような粒 子形状を選択すれば良いと思われる。このような点 は，楕円柱と回転楕円体の結果に現れ， $\omega_{2}=0.1$ 程度 の薄いリボン形状か, $\omega_{3}=0.01$ の扁平な円板形状が 好ましいことがわかる。本研究では，実際的な取り扱 いの簡単さの観点から，後者の扁平円板形状を選択す ることにする。

$3 \cdot 35$ モードガラス転移点分布の結果 巨視的

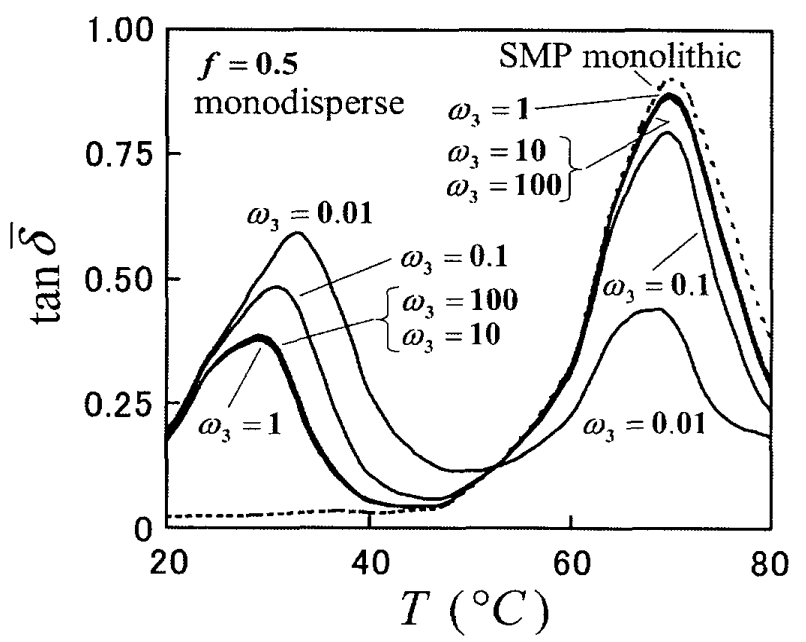

Fig. 6 Macroscopic loss factor (spheroid)

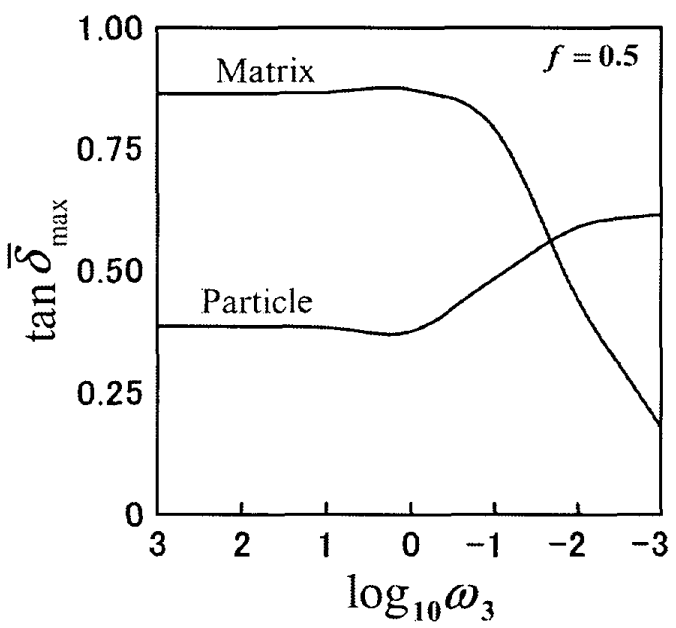

(c) Spheroid

Fig. 7 Peak in macroscopic loss factor versus aspect ratios 
損失係数 $\tan \delta$ の值が 0.3 程度であれば制振材料とし て使用できるという観点から図 6 の結果を見ると， $50^{\circ} \mathrm{C}$ 打ける $\tan \delta$ の落ち込みを改善する必要があ る.このためには, 前節で定めたアスペクト比 $\omega_{3}=$ 0.01 の粒子のガラス転移点 $T_{g}$ 分布を, この $50^{\circ} \mathrm{C}$ 中心とした正規分布状に設定すれば良いと思われる。 若干の試行錯誤の後に得られたガラス転移点 $T_{g}$ 分布 の確率密度 $H$ の結果を図 8 に示す。図示したように,

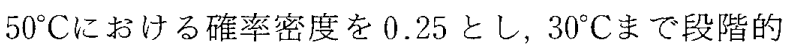
に減少させるとともに，母材の $70^{\circ} \mathrm{C} と 50^{\circ} \mathrm{C}$ 間を若 干補完するように設定した。このような 5 モード分布 を用いて求めた巨視的損失係数 $\tan \bar{\delta}$ と巨視的岡性率 原の結果をそれぞれ図 9(a) と図 9(b)に示す.

図中の破線は母材単体の結果(1)である。図より， $70^{\circ} \mathrm{C}$ における巨視的損失係数の值は，母材単体のそれ に比べてかなり隇少してはいるものの, 約 $30^{\circ} \mathrm{C} ら ら$ $70^{\circ} \mathrm{C}$ に渡って損失係数はほぼ一定であり，また，その 值は制振材料として使用できる值である 0.3 近傍を示 していることがわかる. 図中の1点鎖線の結果は, 比 較のために示した球形粒子を用いた前報の結果 ${ }^{(6)}$ で ある。これらの結果より, 扁平な円板形状の強化基材 を用いた本モデルの巨視的損失係数は, 球形粒子を用 いた前報の結果に比べて, $60^{\circ} \mathrm{C} \sim 80^{\circ} \mathrm{C}$ おいては減少 しているものの, $30^{\circ} \mathrm{C} \sim 60^{\circ} \mathrm{C}$ 範囲では逆に大きくな っており, 温度変化に対してさらにフラットになって いることがわかる。この解析は, 扁平な円板形状の粒 子を体積含有率 $50 \%$ 含むものであり，このような材料 を実際に創生する際には，程度の差はあるものの粒子 同士の接触，すなわちパーコレーションが生じること は避けられないものと思われる。複合材料の巨視的な 熱伝導率や電気伝導率を論じる際には,パーコレーシ ヨンが生じた場合に, 粒子を伝って熱や電流が流れる

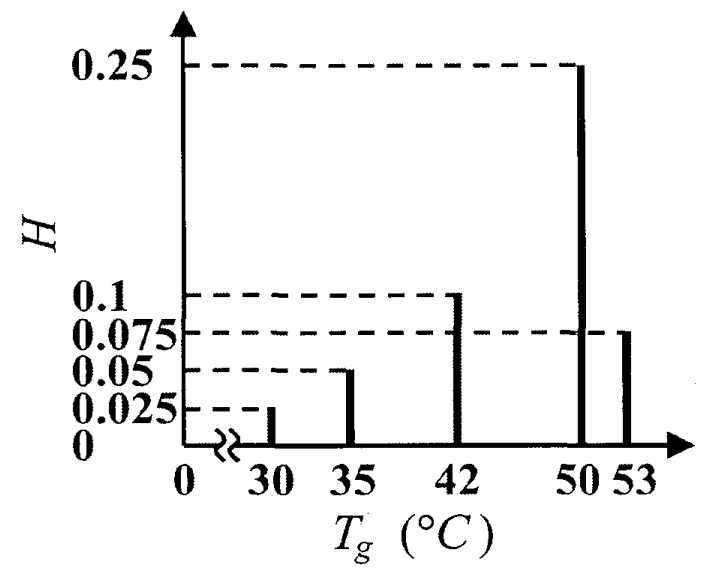

Fig. 85 mode type of distribution of $T_{g}$ of the particle
ため，その影響はかなり大きくなるが，損失係数はエ ネルギー量から算出されるものであるため, これに及 ぼすパーコレーションの影響は，熱伝導率や電気伝導 率に比べて比較的小さいものと考えられる。したがっ て, 図 90 解析結果は,パーコレーションが生じた場 合には適用できないものの，少なくとも粒子のガラス 転移点分布に加えてその形状も工夫することで，幅広 い温度範囲で良好な制振特性を有する材料が創製でき る可能性を示唆していると考えられる.

\section{4. 結言}

本研究は, 形状記憶ポリマー (SMP) 母材中に, 種々 のガラス転移点を有するSMP 粒子を含む状態を想定 し，粒子の形状とガラス転移点分布を工夫することで, 広い温度範囲で良好な制振特性を有古る高分子系複合

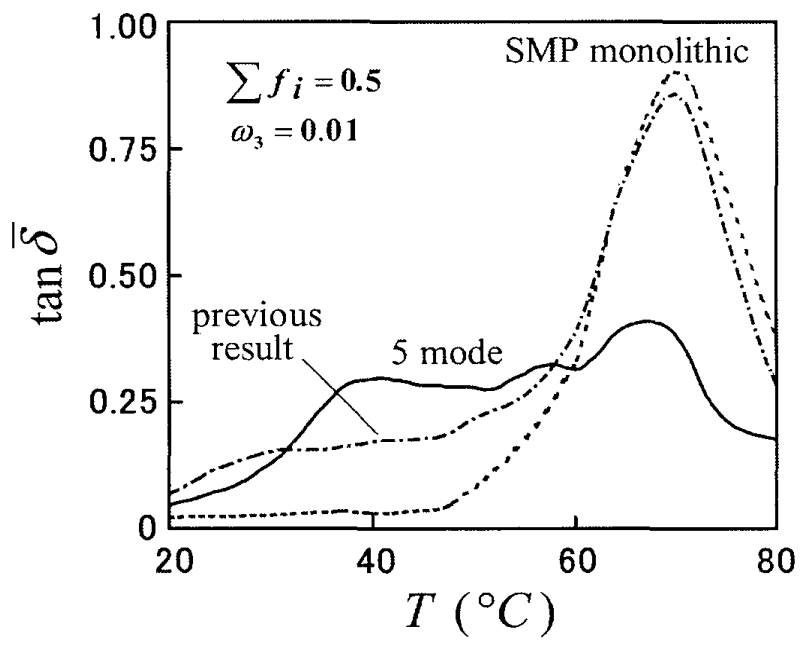

(a) Macroscopic loss factor of the SMP composite (5 mode type of $T_{g}$ distribution)



(b) Macroscopic shear modulus of the SMP composite (5 mode type of $T_{g}$ distribution)

Fig. 9 Macroscopic loss factor and shear modulus of the SMP composite ( 5 mode type of $T_{g}$ distribution) 
材料開発の可能性を検討したものである。具体的に SMP 粒子形状とガラス転移点分布を設定し, マイク ロメカニックスの手法を用いて複合材料の巨視的損失 係数を解析した結果, SMP 粒子のアスペクト比によ ってその值は大きな影響を受けることがわかった。ま た，薄い円板形状のSMP 粒子を用いて，そのガラス 転移点分布を工夫することによって，広い温度範囲で 巨視的損失係数が比較的一定となるような材料が創製 できる可能性があることが確認できた。

\section{文献}

(1) Tobushi, H., Hayashi, S. and Kojima, S., Transactions of the Japan Society of Mechanical Engineers, Series A, Vol. 57, No. 543 (1991), pp. 2760-2766.

(2) Mura, T., Micromechanics of Defects in Solids Second,
Revised ed., (1987), pp. 449-455, Martinus Nijhoff Publishers.

(3) Araki, S., Yamashita, H., Mizutani, N. and Sugimoto, A., Transactions of the Japan Society of Mechanical Engineers, Series A, Vol. 70, No.698 (2004), pp. 15141521.

(4) Tobushi, H. and Hayashi, S., Science of Machine, Vol. 45, No. 11 (1993), pp. 1136-1140.

(5) Tobushi, H. and Hayashi, S., Science of Machine, Vol. 46, No. 6 (1994), pp. 646-652.

(6) Araki, S., Yamashita, H. and Minami, A., Transactions of the Japan Society of Mechanical Engineers, Series A, Vol. 71, No. 701 (2005), pp. 157-164.

(7) Mori, T. and Tanaka, K., Acta Metallurgica, Vol.21 (1973), pp. 571-574.

(8) Araki, S., Ono, H., Yamada, S. and Saito, K., Transactions of the Japan Society of Mechanical Engineers, Series A, Vol.67, No.659 (2001), pp. 1140-1147. 